MANOUSOS KAMBOURIS

355.48(38:355)"-0331"

The Association of Historical

COBISS.SR-ID 264114444

Studies KORYVANTES,

Original research article

Athens, Greece

E-mail:mekambouris@yahoo.com

Received: April $19^{\text {th }} 2018$

SPYROS BAKAS

Accepted: April 30 2018

The Association of Historical

Studies KORYVANTES,

Athens, Greece

E-mail: koryvanteshoplites@gmail.com

\title{
GAUGAMELA 331 BC: THE TRIUMPH OF TACTICS
}

\begin{abstract}
The Battle of Gangamela (331 BC) is one of the most famous in History due to its impact, but also due to the imbalance of the antagonists and the tactical dispositions, choices and command style which determined the victor. In this study a number of less obvious main issues are tackled: Alexander used a modular method of tactical disposition, based on task forces structured by certain units with good chemistry between their commanders and men; these units were used consistently in terms of position, mission and operating procedures, rules of engagement and sequence. Whatever little variation is observed, had been imposed by the enemy and the environment/terrain. Moreover, the raid to the camp of Alexander as described by Arrian and Diodorus refers to its main base camp, out of direct sight and not to the expeditionary one from where he emerged the day of the battle. The raid itself was not executed as indicated by Arrian, whose sources rather described a breakthrough and turn around action from Persian cavalry units, mistaken by himself for the raiding action and units. Additionally, Alexander's army seems to have been organized, since before the battle of Issus and till after Gaugamela, to a tertiary rather than a binary basis, the latter being standard for Greek-type armies. This tertiary structure permitted increased flexibility in tactical dispositions. Lastly, and most importantly, the tertiary structure applied in a very specific manner allowed the formation of the double-phalanx of Alexander in Gaugamela which pricks on the mind and thought of historians ever since. This double phalanx was formed within and by the standard Macedonian phalanx brigades (Taxeis), which were deployed in two echelons each, the second echelons collectively constituting the hind part of the double phalanx; this model is contrary to the usual concept that the hind phalanx was constituted by allied Greek and perhaps mercenary hoplite units.
\end{abstract}

\section{KEYWORDS: ALEXANDER THE GREAT; DARIUS III; BATTLE OF GAUGAMELA; STANDARD DI- SPOSITION; DOUBLE-EDGED PHALANX; TERTIARY ORGANIZATION; PHALANX; COMPANION CAVALRY; HYPASPIST CORPS.}

The Battle of Gaugamela in $331 \mathrm{BC}$ was the death knell of the Achaemenid Empire, its third and last battle under the imperial standard against the invading army of Alexander the Great. Despite the detailed accounts, which are far less contradictory than, for example, the ones on the Battle of Granicus in 334 BC, there are many unexplained issues and contested views. By using the ancient sources in the light of their biases or these of their primary sources and by comparing them with organizational, drill and technical limitations and capabilities we try to unravel some of the facts of the most incredible ancient battle. 


\section{STRATEGIC CONTEXT}

In $333 \mathrm{BC}$ Alexander decided to completely destroy the Persian seapower from and at the land, as he was already accomplishing (Arr. Anab. I.XXIV.3) instead of pursuing King Darius so as to finish off the war at one strike after the victory at Issus (Arr. Anab. II.XVII), resulted in a well-organized occupation of all Mediterranean shores of the Persian empire. However, at the same time it allowed the raising of another grand army by Darius due to the time afforded to the defeated state and monarch. This army, assembled at Babylon (Green P. 1992) comprised mainly of elements uncommitted in Issus, as were the units from the eastern satrapies (Arr. Anab. III.VIII.6) defined as of the position of Persia proper. Moreover, remnants of the army of Issus were also included (Arr. Anab. II.XIII.1-III.XI.7 ), and, the most important thing, extensive, first -hand experience on the Macedonian new fighting tactics and weaponry had been factored in the new army, starting with but not limited to the issue of longer spears and swords (Diod XVII.LIII.1).

Alexander had secured the volatile Phoenicia and the potentially untrustworthy Egypt (Anson E.M. 2013) and took his army leisurely from Memphis against the new Persian royal army (Arr. Anab. III.VI.1 \& VII.1). From Tyre he ascended from the main road in Phoenicia to Thapsacus (Arr. Anab. III.VII.1), striving both to pacify the interior and to use a road suitable for his artillery and siege parks (Engels D.W. 1980, pp 54-70) which now could not be ferried by the sea (Arr. Anab. II.XXVII.2) and had developed considerably after the sieges of Tyre and Gaza.

Possibly Alexander was quite happy to find Persian loyalists from the whole empire concentrated and assembled within reach, to crush in one battle (Diod XVII.LVI.4), but this was only one plan of action: although he meticulously projected an image of bold, even reckless, impatient and dashing general, he was not entirely such. The storming of the Cilician gates (Arr. Anab. II.IV-3) and the prompt engagement at Granicus (Arr. Anab. I.XIII.6) were testaments of his dashing. The final action in Pelium (Arr. Anab. I.VI.9-10) and the attempt at Mindus (Arr. Anab. I.XX.5) were bold, night actions to catch enemies off guard; but the action in Halicarnassus proper (Arr. Anab. I.XX.2 and I.XXII.7) and the one in Thebes (Arr. Anab. I.VII.10) were patient, leisurely siege actions, not very vividly nor astutely pursued. When unnecessary risks, in the form on naval engagements, emerged, he had been really cautious and did not respond to repeated challenge (Arr. Anab. I.XVIII.6). The surprise winter campaign of 334 BC (Arr. Anab. I.XXIV.3) was followed by weeks of inaction in Cilicia (Arr. Anab. II.VI.4), prolonged sieges in Tyre and Gaza and a really comfortable schedule in Egypt, which resulted in almost two years between the second and the third major clashes.

This behavioral inconsistency was showing a leader enabled with all needed qualities and using them in discretion, thus increasing the uncertainty of the enemy. Thus, when Alexander crossed the Euphrates, neither he nor Darius were looking forward for a head-to-head clash in equal terms, a set-piece battle. They intended to capitalize on any possible advantage they had or they could create, and negate the opposite part any such opportunities. Darius now believed what the late Amyntas, son of Antioch, an expatriate nobleman of Alexander, had told him before the Battle of Issus (Arr. Anab. II.VI.3\&6), that Alexander would come to meet him in arms, and intended to build up all possible advantages. From a new model army (Diod XVII.LV.1) to better selection of the battlefield (Diod XVII.LIII.3), improved tactics, full use of technology and technical resources (Diod XVII.LV.2 \& LIII.1) and a smartly executed opening campaign of exhaustion laid at the path of his opponent (Diod XVII.LV.1). Alexander had no intention to play by these rules, and instead of dashing towards Darius in the general direction of Babylon, after crossing Euphrates, continued east (Stein A. 1942) and forded Tigris (Arr. Anab. III.VII.5). 
This was a strategic masterstroke. It nullified all the preparations of Darius at the expected convergence path. At the same time his army had a cooler walk south of Kurdistan instead of the scorched Mesopotamia, which most probably would have been stripped from fodder and other supplies (Arr. Anab. III.VII.3). Thus the exhaustion strategy failed. But also the dashing and unpredictable character of Alexander allowed him a chance to repeat the storming of the Cilician Gates in a gigantic scale: moving down along Tigris he was in a position to burst through Behistun to Media (the escape road selected by Darius after the battle- Arr. Anab. III.XVI.1) and from there to Persia, while only militias would be there-and these in low alert, as the gigantic imperial army was practically in front of them, outside of the pass.

Darius was trying for years to transfer the operations in Greece (Arr. Anab. II.I.1; Diod XVII. XXX.1), a strategy which worked superbly against the Spartans in 395 BC (Xen Hellen IV.II.1-3). Instead of this, Ekbatana in Media and then Persepolis, the royal city and birthplace of Achaemenid rule, where to be stormed by the agile and flying macedonian army while the host of the King of Kings was between Babylon and Susa, gleaning the supplies of the fertile crescent.

This made Darius move his gigantic host north-east to Gaugamela (Arr. Anab. III.VIII.7), in order to prevent this move. Alexander would not attempt a breach at Behistun and Zagros mountains with the royal army close by. Still, the morale of the achaemenid host, which were found to run to intercept instead of waiting at their comfortably established base at Babylon (Diod XVII. LIII.1) would have suffered a blow. Similarly, all preparations of the battlefield and the logistics set into place were abandoned and eliminated overnight. The scales were coming towards leveling, but there was still a long way to go.

\section{PREPARATIONS AND INTENTIONS}

\section{The Persian side}

Darius was proving a smart and intelligent man with good reflexes. His gigantic host (Arr. Anab. III.VIII.6) moved relatively fast to avert the threat to the Motherland and impose an all-out battle instead of a contest by maneuverability and generalship. Alexander would have to fight it out with a huge disadvantage in numbers at an advantageous and prepared field of battle (Arr. Anab. III.VIII.7), although not as advantageous and well-groomed as the previous near Babylon.

Although Alexander found the battle order of Darius after the end of the fighting in Gaugamela (Arr. Anab. III.XI.3), it is usually maintained that the Persian army was mainly cavalry, due to the eastern contributions and the slaughter of dependable infantry in Issus (Arr. Anab. II.XI.8). Still, the massive Mesopotamian levies were infantry, as were big parts of Median and Persian national armies and the gigantic host of the Achaemenid kingdom was infantry-heavy by almost 20:1 in Gaugamela (Arr. Anab. III.VIII.3-6). The new long weapons Diodorus mentions (Diod XVII. LIII.1) were most probably issued to the infantry, which had performed very poorly at Issus, in contrast with the cavalry and the Greek mercenaries-which were now down to one tenth of their peak number (Arr. Anab. II.VIII.5 \& II.XIII.1).

In Gaugamela the Persian intention is double and doubly obvious: the deployment indicates an intention for envelopment; the disposition, and in this both new arms and new weapon systems must be included, clearly indicates provision to counter frontal charges by qualitatively superior forces. Nothing might be found missing; but, then, practically the same had been the concept in Issus, as well. The means changed in between, the ends did not.

Darius had enough with the Greek tactics which he tried at Issus. The defensive positioning of a hoplite/ pseudohoplite phalanx behind a river (Arr. 
Anab. II.VIII.5-6), the palisades to protect accessible positions (Arr. Anab. II.X.1) and the cavalry posted at the flanks (Arr. Anab. II.VIII.10) were all Greek, not Persian traits-and the same may be said for the deep battle formation (Arr. Anab. II.VIII.8). Palisades in the battlefield were the specialty of the Thebans against the Spartans for 20 years (389$371 \mathrm{BC}$ ), as were very deep infantry formations (Thuc IV.93; Xen Hellen VI.IV.12 \& IV.II.18). And from the mid- $5^{\text {th }}$ century, when cavalry operations came into vogue of Greek military practice, the posting was usually at the flanks, with very few exceptions, contrary to the Persians who preferred positioning it in front of the infantry, as in Kunaxa 401 BC (Xen Anab I.VII.11 \& I.VIII.24), Pactolus 395 BC (Xen Hell III.IV.23-24) and Granicus, 334 BC (Arr. Anab. I.XIV.4).

Moreover, there is no mention in Gaugamela for Hellenized Persian Infantry, as mentioned in Issus. In Issus, two 30,000-strong bodies of Kardaka professional home troops were given hoplite gear and positioned at the flanks of 30,000 Greek mercenary hoplites (Arr. Anab. II.VIII.5-6). The 30,000 is a very special figure, denoting an army corps according to Herodotus (Sekunda N. 1989, 84) made up of 3 baivarabam of 10,000 each. it was most probably the standing, professional Persian army, hastily re-equipped to increase the successful hoplite paradigm, but at Issus they were cut to pieces by both the Macedonian cavalry and phalanx, due to the latters' longer reach in terms of shaft weapons (Markle M.M. 1977;1978), a fact which prompted Darius to issue longer ones (Diod XII.LIII.1); and to the much better training in this kind of warfare (Gaebel R.E. 2002), which prompted Darius to execute a vast drill and discipline-heavy training program (Diod XVII.LV.1).

\section{The army of Alexander}

The spacey plain of Gaugamela allowed the deployment of the Persian host to an astonishing width. This fact denied any thought that the
Macedonian army might match the enemy width by elaborate deployment of units, as done in Issus and, to be accurate, in Marathon 490 BC (Herod VI.111) for the first time. In Issus the resulting reduction in depth/density was a constant source of consternation for Alexander (Arr. Anab. II.IX.3 $\& 4$ ) and possibly the reason for the spontaneous gap which led to the bitter fighting between Greek mercenaries of the Persians and the phalanx (Arr. Anab. II.IX.4-6). Thus, in Gaugamela Alexander could form his army deeper and more compact, as the difference in width would be irrelevant: it would be the maneuver, not the deployment, which was intended to cover the front. By making the formation compact, Alexander succeeded in (1) making harder a Persian breakthrough; (2) invited to the point of complete confidence flanking attempts by the Persians in both flanks; (3) ensured accuracy and perfect coordination in the execution of maneuvering of the whole army.

The constitution of the army of Alexander is a mystery. With few installments of reinforcements (totaling at the very least a sum of 8,750 men by the day the march from Memphis towards Tyre and Gaugamela started, of which 7,200 infantry) and losses due to garrisons and casualties, it is by $1 / 3$ larger than the invasion force. This bolsters the view that the invasion force inventoried by Diodorus (Diod XVII.XVII.3-6) does not include the remnants of the advance force positioned in Asia for 3 years, which most probably accounts for the differences among historians on the strength of Alexander's invasion army (Brunt P. 1963). Arrian (Arr. Anab I. XI.3) only mentions a 35,000-plus force moving to cross to Asia, which matches the number of Diodorus. It also implies a grand total, with support units, such as the engineer corps (artillery and siege, bridging, fording and building units, plus logisticians). All these units were most probably left behind when the clash at Gaugamela was imminent and guarded closely (Arr. Anab III. XII.5), as they could not interfere in a pitched battle where the opponent could retake the initiative originally ceded to encourage battle at the field of 
his own choosing and preparation.

The core was the Macedonian army, but even there, only a fusion of our sources allow definite conclusions on the organization and structure. Massive reinforcements had not yet arrived but for the class of 333 BC, 3,000 infantry and 300 cavalry, which had joined the army in Asia Minor, in Gordium (Arr. Anab. I.XXIX.4). Since then, only allied and mercenary contingents had arrived- although Brunt argues against this conclusion (Brunt P. 1963) and this provides even ampler numbers to account for casualties' replacements. Thus, the core of the army were the phalanx regiments, enumerated to six by Arrian (Arr. Anab. III.XI.8-10), plus the 3 Hypaspist brigades (also enumerated by Arrian, in III.XI.9), and the companion cavalry, enumerated by Diodorus (Diod XVII.LVII.1) and by Arrian (Arr. Anab. III.XI.8) to seven squadrons and the Royal Squadron on top of them.

The principles applying are that a heavy infantry unit is 10 times the size of a respective cavalry unit; that royal guard units are double the size of regular ones (Rzepka J. 2008) and that the Macedonian army, at the very latest from the Battle of Issus has its heavy line elements organized on a tertiary and not on the binary basis common in all Greek or Greek-type armies. Given that Arrian equates two Companion cavalry squadrons to 300 cavalrymen (Arr. Anab. II.IX.3-4) at Issus, the Companion Squadron/Ila must be 150 -strong, the phalanx brigades/Taxeis are 1,500 strong each, the Hypaspist Corp double that, 3000 as is indeed mentioned (Arr. Anab. V.XXIII.7), and the royaI squadron should field 300 Cavalrymen (Tarn W. W. 1948, 162-3). It is most probable that this reorganization took place in Gordium in $333 \mathrm{BC}$ before the Battle of Issus, using the manpower brought from Macedon by the 3 Generals (Arr. Anab. I.XXIV.1-2). The 3,000 freshly recruited Macedonian infantrymen allowed for one more regiment of 500 men for each of the 6 phalanx Taxeis brigades, and the same goes with the 300 cavalrymen, distributed by 50 -horse units to 6 Companion squadrons, beefing them from the 100-strong level implied more than once (Arr. Anab. I.VI.1 \& I.XVIII.1) into the 150-strong attested in Issus (Arr. Anab. II.IX.3-4).

Moreover, the Bodyguard is perhaps 200-strong (Arr. Anab. IV.XXX.3); a mixed force of Hypaspists and Bodyguards up to 700 (Arr. Anab. IV.XXX.3), can be broken to a standard unit (500-strong) of Hypaspists, and thus the rest, are the bodyguards. Possibly the bodyguard under Hephestion is committed along Companion cavalry in Gaugamela, according to Diodorus (Diod XVII.LXI.3).

Macedonian light cavalry and archers, might be steadily organized in a binary basis, thus the latter are probably divided in two subunits and are explicitly mentioned as a different unit than the Cretan archers in Issus (Arr. Anab. II.IX.2-3).

Thus the heavy Macedonian infantry accounts for 12,000, the archers for perhaps 1,000 more, the heavy cavalry for 1,400 and the light scout cavalry for an unknown number, but perhaps at 400-600; this is hardly 15,000 , less than a third of the 47,000 grand total (Arr. Anab. III.XII.5). If esquires are added, which had an active role in combat, at least at this battle (Arr. Anab. III.XIII.6), there were at the very most one for each cavalryman and one every 10 infantrymen (Front. Strat. IV.I.6), this equals maybe 3,000 men (the bodyguards most probably had no esquire), pushing the total to 18,000 , of whom 2,000 cavalry. Moreover, the headquarters-high command, scientific cadre, civil administrative, religious, treasury, courier, medical and siegecraft personnel cannot be calculated, but are over this total, despite the use of infantry for many secondary missions as is foraging and engagement in massive engineering feats.

Moreover, the Macedonian troops are THE main battle line in Gaugamela. Two massive flank guards are expressedly described and are comprised mostly by non-Macedonian units, with few light cavalry and light infantry exceptions. These formations were at a field strength of approximately 5,000 for the right flank guard and probably an equal number for the left, pushing the total 
to 28,000 , without counting esquires, which they might or might not have. And this is all of the Army of Alexander which took part in the battle. Arrian speaks of a second phalanx, behind the first echelon, but he never mentions one of its units by name but one, the royal hypaspists (Arr. Anab. III.XIII.6).

The usual explanation forwarded by historians is that the second echelon (Arr. Anab. III.XII.1) is made of southern Greek hoplites (Devine A. M. 1975; Griffith G. T. 1947) not mentioned due to disaffiliations of the primary sources, especially of Ptolemy. That may be; though Kleitarchus, the chief source of Diodorus (Steele R. B. 1922; Prandi L. 2012) was in Alexandria under Ptolemy I. Still, eliminating the whole body of such troops is a bit too much, especially for Arrian who is a soldier and understands the nature of things.

Actually, a body of allied Greek troops is identifiable at the left, in the flankguard, led by Koiranos (Arr. Anab.III.XII.4); Arrian explicitly calls this unit "Allied Greek Cavalry" (ibid). Though, he also mentions allied Greek cavalry at another position at the left (Arr. Anab. III.XI.10), and led by Erigius. The latter is elsewhere mentioned as the chief of allied cavalry (Arr. Anab. III.VI.6), whereas a somewhat shady text mentions a certain Kalanus as being appointed commander of the allied infantry (Arr. Anab. III.V.6). This unit has the same function with the mercenary unit of Kleandrus in the right flank (Arr. Anab. III.XII.2), which can be identified with 4.000 mercenary Greek infantry committed to himself and delivered during the siege of Tyre (Arr. Anab. II.XX.5). To identify 'Kalanus' with 'Koiranus' is not a long shot, especially in Greek lowercase scripts, where, in poor handwriting, 'oi' can be mistaken for ' $a$ ' and vice versa -which leads to correcting ' $r$ ' to ' 1 ' and vice versa. After all, there is a very similar case with the astute Menidas, a protagonist in Gaugamela as commander of a mercenary cavalry troop (Arr. Anab. III.XII.3), who must be identified with 'Menoitas', bringing at Memphis such a unit, 400-strong (Arr. Anab. III.V.1).

The most probable solution lies with the pro- fessional way the Army of Alexander was conducing warfare. Alexander never deployed, in any of his 4 major battles, all his forces. Actually he committed almost half of them, being more conservative than the Spartan Authorities which sanctioned expeditions with up to $2 / 3$ of the available forces of each ally (Thuc II.10).

He did not commit much more than half the national Macedonian army in Asia, leaving the rest with Antipater. In Granicus no allied and mercenary infantry are present, and in Issus even a whole taxis of the phalanx is -or, actually, might be considered-absent (Arr. Anab. II.VIII.3-4). For these battles there is a partial argument; he did not wanted to pit southerners against their mercenary cousins in Persian service-a weak argument in view of civil warfare and stasis in the Greek world for the last 150 years, but, truth be told, since its historical dawn.

But the pattern continues in Gaugamela and in Hydaspes. A more integrated approach might reveal that a considerable force was always left to guard a base, a camp or a bridgehead, to secure the rear and to provide a safe heavens if things do not evolve as wished. Thus, in Granicus the bridgehead and the dockings of the invasion fleet must have been heavily guarded for any surprises by independent Persian cavalry or any mobile force coming from the south, along the Ionian Coast; in Issus the pass and the entrance in the valley (Arr. Anab. II.VIII.1-2) and in Gaugamela a well-fortified camp, at less than a day's march from the battlefield (Arr. Anab. III.IX.1 \& III.XII.5). Arrian specifies that Alexander took the army with their weapons only to the field in Gaugamela (ibid), aiming for-or fainting- a dawn attack (Arr. Anab. III.IX.2), but at the end enforcing exhaustion by keeping the Persians deployed in battle order and awake (Arr. Anab. III.XI.2), as had happened in Salamis in 480 BC (Herod VIII.76). The anecdote with Alexander sleeping heavily into the day (Diod XVII.LVI.1-2) must be seen into the same light; to unnerve and further wear down the Persian host. 
It is more than certain that the elaborate train of siege park, artillery, the prisoners of war, possible hostages, the captured family of Darius and the acting court of Alexander which practically administered the conquered lands and Macedon were not dragged along at this forced march towards Darius, did not bivouac in the open (Arr. Anab. III.IX.4), on a rather steep hillcrest (steep enough to provide some security from the Persian mobile units, that is chariots, elephants and heavy cavalry), and did not march the following day against the Persian host. All these units were left behind to the major base camp (Arr. Anab. III.IX.1), along with a considerable force of 5,000 Thracians for their protection, for the defense and security of the camp, and for guarding the prisoners (Arr. Anab. III.XII.5). The fate of base camps has proven decisive both before and after Alexander, as in Marathon 490 BC (Herod VI.114-5), Kunaxa 401 BC (Xen Anab I.X.18-19), Aegospotami 404 BC (Xen Hellen II.I.28), Himera 479 BC (Herod VII.167; Diod XI.XXII.1-2), Plataea 479 BC (Herod IX.70), Thermopylae 191 BC (App Syr. IV.18-19), Magnesia 190 BC (App Syr VI.36).

It is often overlooked that the army of Alexander in Gaugamela is essentially the one of Issus, minus respective casualties of that battle, and additional casualties in Tyre, Gaza and Egypt. On the other hand, at the very least 5,000 mercenaries had been added: 1,000 mercenary cavalry who joined in Egypt; that is broken to 400 southern Greek under Menidas and 500 Thracian under Asclepiodorus (Arr. Anab. III.V.1), and 4,000 infantry under Kleandrus, which joined in Tyre (Arr. Anab. II.XX.5). The existence of flank guards, the generic structure, the composition of the wings and the exact disposition and order of the phalanx Taxeis are identical, despite the 2 years. There are some qualitative changes, as the 5,000 new mercenaries are posted to the right flank guard so as to allow the sum of the companion squadrons to be used at the focal point and to replenish the stock of mercenary infantry which was used up in garrison duties. For comparison, the army of
Granicus although a bit more than a year distant to the one of Issus, sows little resemblance. Of course, differences in battle order are a function of the conditions and of the selected tactics, but the differences are many.

Still there are some standard operating procedures in all three battles: The most obvious is the mix of light infantry to the heavy cavalry (Arr. Anab. I.XVI.1), a practice of Boeotians and perhaps Thessalians, celebrated by Xenophon (Xen Hell VII.V.24).

The second is the ability of Alexander to move laterally on the battlefield without changing the front and disposition of his units. In Gaugamela it is done by the whole army in a diagonal fashion (Arr. Anab. III.XIII.1-2), but the Companion cavalry had done it before at Granicus (Arr. Anab. I.XIV.7).

But the most important and the least analyzed is the structure of mixed strike packages unleashed against far superior cavalry forces. Alexander used them in all 4 major battles and the use was in some cases multiple in spatiotemporal terms; thus it could happen more than once in the same battle. The basic idea is a shock action by heavy cavalry to both disrupt and pin down the opponent. Light elements, infantry or cavalry, support the sock action to protect the engaged troops and increase their lethality in the disrupted enemy lines (Arr. Anab. I.XVI.1), while heavy infantry charges at the double to engage the pinned enemy, dislocate it and route it.

The idea is not of Alexander's. The best use is in Pactolus, 395 BC, by Agesilaus (Xen Agesil I.31; Xen Hellen III.IV.23-24), but seems quite standard in $4^{\text {th- }}$ century Greek battlefields. Still, its origins must be even older, as the 10,000 of Xenophon implement it with an ease implying a standard skill for professional troops (Xen Anab VII.III.46 ). Alexander uses this sequence to open the battle in Granicus and secure a bridgehead (Arr. Anab. I.XIV.6); to safeguard the rear of his right wing at Issus and perhaps to bolster his left wing which will be charged by an enormous mass of cavalry (Arr. Anab. II.IX.3-4). In Hydaspes (Arr. Anab. V.XIV.1-2) he 
does the same, to engage an intercepting enemy force, and at Gaugamela both his flank guards are configured on this basis (Arr. Anab. III.XII.2-3 \& 4-5) to withstand masses of enemy cavalry.

\section{Maneuvering and engagements}

The advance of the army of Alexander is an issue which taps onto the heart of the battle mechanics of the battle. The formation is perhaps obvious, and the same might be maintained for the drill; the intention is another dimension altogether, oftenly disregarded one.

In here another issue arises: Alexander spent the night at a summit (Arr. Anab.III.IX.4 \& X.1), which means that Persians would be able to see his order of battle as he descended to the plain- or he deployed after descending. This is also consistent with the canted back flanks/ flankguards, which require some level space behind the main line.

The drill had been most probably the turn at 45 degrees right; practically, a half-turn "spearwards" (Arr Ars Tact XXI.1) and then advancing. Same sideways move, but by cavalry only, had been executed in Granicus (Arr. Anab. I. XIV.7). The formation, though, is more obscure. The whole battleline might have been moving simultaneously, which would present as little challenge in timing as possible; but still, moving en echelon, with different divisions starting the march successively, not simultaneously, would produce the added and highly desirable effect of denying the left, where envelopment was to be expected, for as long as possible. Once the maneuver at a slant was to cover the Persian front towards its left wing, his own right would become exposed.

Alexander had reconnoitered extensively the previous day (Arr Anab III.IX.5); and he spotted the uneven ground at the left flank of the field. Arrian says Darius camp was not well protected and safely entrenched (Arr Anab III.XI.1)- a sign it was occupied for a short time before the arrival of Alexander. And this was the reason for keeping his troops staying put in battle order, to avert the night raid advised by Alexander's staff (Arr. Anab III.XI.1 \& IX.3 respectively). It is understood that traps might have been a legitimate concern for the Macedonian staff (Arr. Anab. III.IX.4), but they actually were not implemented as they would have marred the perfect Persian battlefield. The reconnaissance would have made this clear to Alexander (Arr. Anab. III.IX.5), which means that he quite simply was not in favor of a night action in this particular case-an action expected by Darius.

All these beg the question of the character of the uneven ground at the left of the Persian battle line (Arr. Anab. III.XIII.1-2). If it was rough enough to cause mobility problems for cavalry, how Bessus shadowed Alexander (Arr. Anab. III. XIII.1-2)?. It most probably was presenting problems to the deployment of the chariots only-as Arrian's wording clearly suggests. Thus, Alexander's slanted move would simply take him out of the threat of the scythed chariots, on grounds where infantry and cavalry would face no particular problems and would be able to maneuver at will. And it was rather improbable for this maneuver to be executed on time so as to evade the onslaught of the chariots. Flanking moves were not new; Xenophon mentions it for Thebans in Nemea, 394 BC (Xen Hellen IV.II.18) as an intentional maneuver, and not as a spontaneous event, as Thucydides determines narrating the First Battle of Mantinea 418 BC (Thuc V.71).

If we take into consideration that the motion sideways also threatened the Persian flank, which would give ample reason to the Persian commander at the left (Bessus) to extend, the move of Alexander would threaten (i) getting out of the killing field of the chariots, and (ii) launching a flanking attack; but, with a decent opposing commander it would not enable Alexander to actually do either. Most probably his aim was to stimulate these reflexes and cause a commotion in the Persian line so as to create a weak point to charge in, not around, and form internal flanks. In Issus, a straight charge did the trick, with the stout xyston 
spears of the companions offering the edge against the hoplon shield and simple dory spears of Hoplites, both Kardaka mercenaries and Greek mercenaries (Arr. Anab. II.VIII.6). But in Gaugamela the new Persian weaponry might have been the reason for having to create a weak point before attempting to charge, a case not very dissimilar to the Battle of Granicus, where an initial charge disrupted the Persian line, caused redeployment and provided a foothold and a weak point (Arr. Anab. I.XV.1 \& 3-4 \& 7). In Gaugamela it was the same in a massive scale, with the successive charges and countercharges between the Persian left flank and the right flankguard of Alexander (Arr. Anab. III. XIII.3-4 \&XIV.1), till the opportunity presented itself for the decisive charge (Arr. Anab. III.XIV.2).

On the contrary, Mazeus, the Persian commander at the right, flanked the Macedonian left much easier as the rightward move of Alexander gave him even more leeway, and send a cavalry detachment to the main Macedonian base. Diodorus account (Diod XVII.LIX.5-8) for the retrieval of the Persian royal family and the successful assault means the main camp. Arrian describes the action of the center which may have gone to the advanced camp, or to no cam at all: they may have wheeled to hit the phalanx from the rear. The $2^{\text {nd }}$ echelon units could not have caught cavalry at the advanced camp, much less at the rear camp. Arrian messes the camp raid with an action at the rear of the phalanx. Persian detachments after flanking at their right, must have enveloped the Macedonian left which deployed defensively to fight at three sides and was pinned down. Either due to solidarity or because he was attacked and pinned as well, the second-left phalanx Taxis also stopped at its tracks and a breach was created (Arr. Anab. III.XIV.4). From this breach, Persian units (definitely NOT the elite units of the Great King's entourage) poured through the Macedonian phalanx (Arr. Anab. III.XIV.5) to attack it at the rear; thus the second phalanx echelon turned to receive this attack at their rear-not to give chase across an open plain (Arr. Anab. III. 6).
These Persian units, attacking from the rear would have front to their own battle order. So, they witnessed firsthand the collapse of the left Persian flank, leaving them behind enemy lines. This condition should have made them to retire fast and in poor order, through the gap they emerged from. These units must have been the ones accidentally intercepted by Alexander and his companions when they dropped the chase and turned left to assist their pressed left wing (Arr. Anab. III.XV.1-2)

Arrian dwells briefly to the turning point of the battle, the action developed by the combined arms attack of Alexander. He never mentions which enemy unit he fell upon, neither himself nor any of the phalanx brigades. His mention of phalanx and companion wedges (Arr. Anab.III. XIV.2) is most unsettling: the proposals of Devine (Devine A. M. 1983) befit rather a show than a tactical reality under pressure. Arrian's description of infantry wedge (Arr Ars Tact XXIX.5) is inapplicable here as the phalanx is deployed laterally: any other deployment, although possible by the tertiary organization of the Taxeis (Fig. 1), would nullify the tactical surprise for the scythed chariots and is not warranted by the sources. A slanted formation with every man lagging a step behind his rightward respective number (parastates) might have been possible (Fig. 2) but remains improbable.

On the other hand, cavalry wedges for the Companion Cavalry charge (Arr. Anab.III.XIV.2) are easy to depict. Arrian clearly mentions them as Macedonian practice since Philip (he does NOT imply a Scythian origin in the Macedonian use, despite the usual liberal interpretation of Arr Ars Tact XVI.6-7). The famous event with the Persian commanders in Granicus (Arr. Anab.I.XV.7-8) is explained perfectly if two wedges clashing frontally are taken into account. Each 50-strong subunit of an Ila forms a wedge (Fig. 3). Though, how these wedges were deployed in Ila and higher echelons is debatable: the tertiary organization of Ilae allowed a wedge of 3 wedges, a line, a column (which is possibly the Ilae Orthae, see Arr Anab. IV.IV.7) or a slanted line (Fig. 4). The formation 

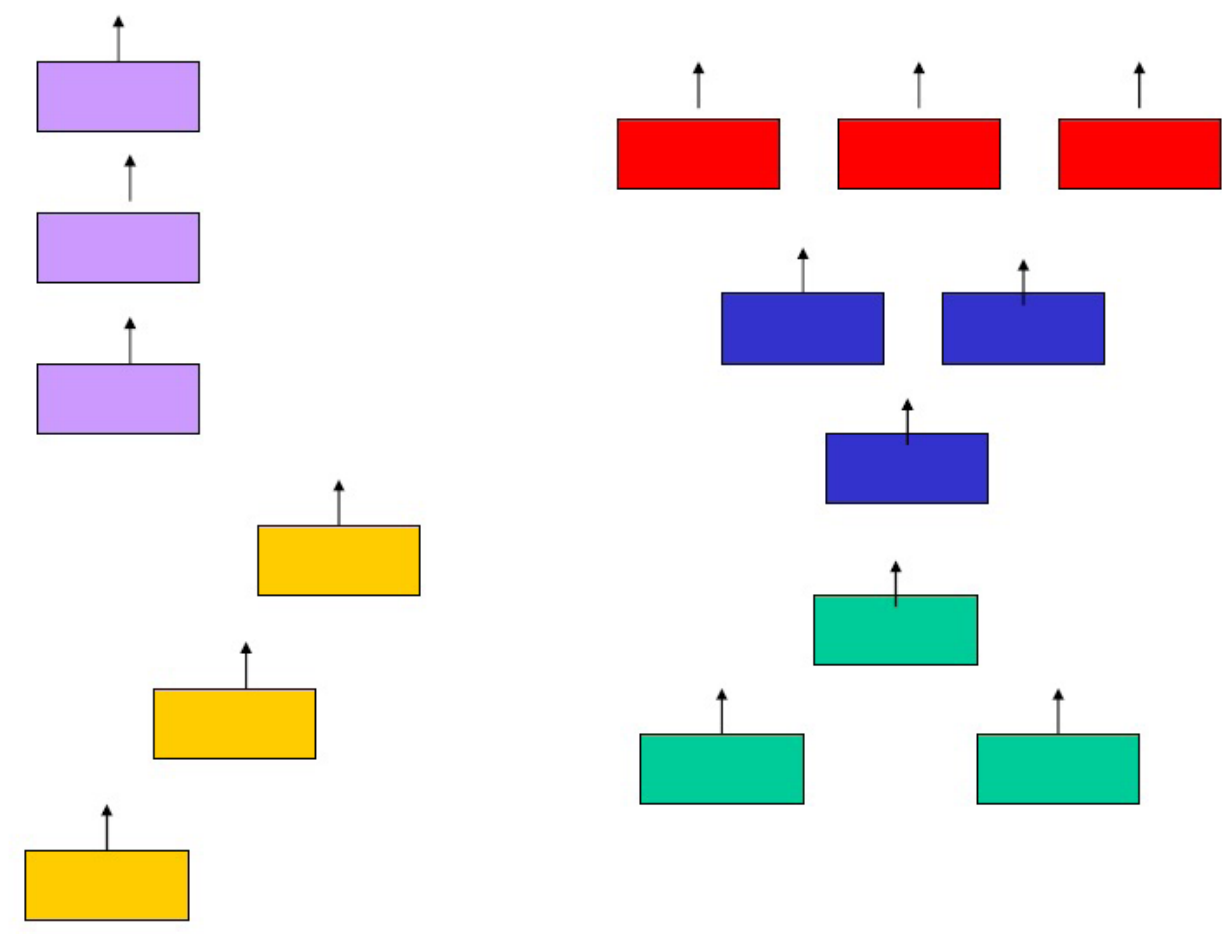

Fig. 1 Possible formations of the 3 Lochoi of a tertiary Taxis

of the seven Ilae adds even more to the uncertainty. The only sure thing is the incorporation of light infantry to support the charging cavalry- the units which initially screened the Companion Cavalry from the chariot attack (Arr. Anab. III.XII.3). The same practice may be assumed for the battle of Issus, though it is not directly attested. But it is expressedly stated for Granicus, and with great effect (Arr. Anab. I.XVI.1). In Granicus, though, two of the three units were assigned to the cavalry commander Philotas directly (Arr. Anab. I.XIV.1).

\section{DOUBLE-EDGED PHALANX}

Arrian mentions a double phalanx at Granicus (Arr. Anab. I.XIII.1), without any other comment, as, regarding heavy infantry, he only provides the disposition of the Macedonian phalanx (Arr. Anab. I.XIV.1-3) before the action. No whereabouts are mentioned for allied infantry units, nor for mercenary infantry, which implies either placement as a rear phalanx or back at the bridge- head to provide base security. The former option is bolstered by Arrian, when referring to Parmenio (Arr. Anab. I.XIII.3) stating that Alexander's army outnumbers the opposite force in infantry-the Persian infantry being estimated at less than 20,000 southern Greek mercenaries (Arr. Anab. I.XIV.4). Thus the double phalanx may be explained as a disposition of march, to be deployed in single line battle order once at the river bank.

But in Gaugamela the double phalanx is explicitly elaborated to a double-edged one (Arr. Anab. III.XII.1), a term adequately explained by the same author (Arr Ars Tac XXIX.1). Additionally, the tactical purpose and relevant orders are clearly mentioned (Arr. Anab. III.XII.1), at least part of its operational employment is attested (Arr. Anab. III. XIV.6) and one of its units is mentioned by name: the Royal Hypaspists, which eliminate Persian scythed chariots after the latter pass through the phalanx openings (Arr. Anab. III.XIII.6). Moreover, allied infantry is securing the left flank guard (Arr. Anab. III.XII.4) as the mercenary infantry does in the right flank guard (Arr. Anab. III.XII.2). 


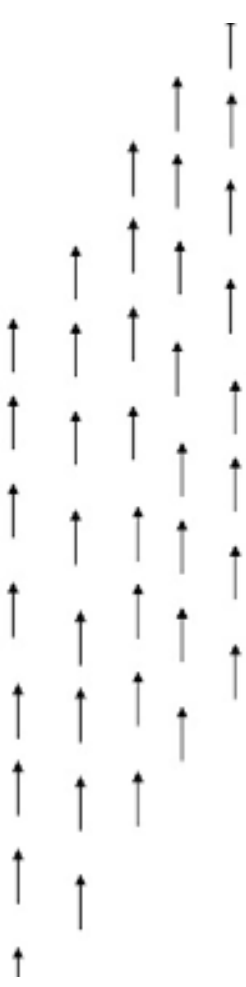

Fig. 2 A possible model for a slanted front in an infantry formation. Each file starts its advance lagging one step from the one at its right

Thus, the hazy second phalanx line cannot have been made up by any other units as usually suggested (Devine A. M. 1975; Griffith G. T. 1947) which would have shaded the first line units, the Macedonian phalanx Taxeis. Cohesion, coordination of front and rear units and, most importantly, troop availability issues make it highly improbable. Rather, a true second phalanx line might be a better guess, a concept up to a point felt but not fully explored by Delbruck (Delbruck H. 1990). The Macedonian infantry Taxeis might have been deployed, each, in two echelons, the front one with two 500-man lochoi, the second with the third lochos (Fig. 5, 6). The rear lochoi, deployed to half depth, so as to cover a front equal to the two front ones, would form a real second phalanx, of decreased depth, equal front, shading the move of the first echelon and ready either to plug any breach or to about-face to meet a threat from the rear; thus any breach and encirclement might be managed, contrary to some views which insist on considering such eventuality outright destructive

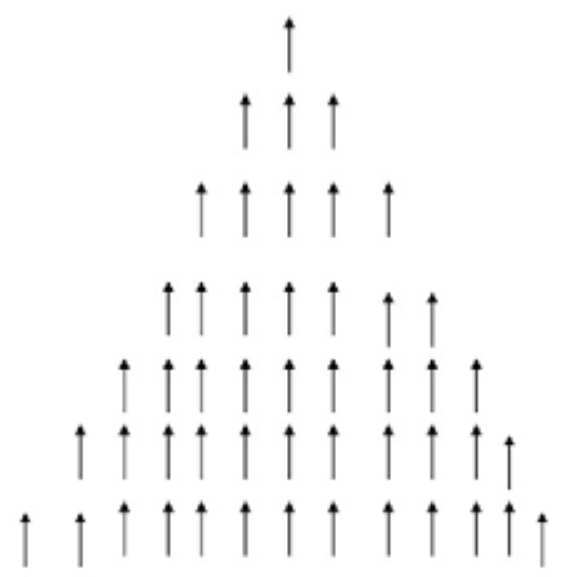

Fig. 3 Macedonian cavalry embolon of 49 cavalrymen in seven rows. Each row covers the rear flanks of the previous, thus explaining the famous incident at Granicus (Arr Anab I.XV.7-8); Cleitus must have been positioned left, second row, to have a shot at the armed hand of the flanking Spithridates

and fatal (Wrightson G.C.L. 2012).This disposition weighs heavily onto Lochos Commanders (Lochagoi) which explains Alexander having them in the briefing before the battle, to give orders and explain the plan (Arr. Anab. III.IX.6). The most probable drill to achieve about-facing must have been, at the time, the Macedonian Countermarch (Arr. Ars Tact XXIII.2 \& XXIV.1), but the Laconian Countermarch might have been better suited if the front echelon had already been in contact (Arr. Ars Tact XXIII.3 \& XXIV.2). The Macedonian army emphasized drill due to its origins dating back to the legacy of Iphicrates in Macedon (Aesch II.26-29) and to the days of Philip II as a hostage in Thebes (Diod XVI.II.2-4).

The same applies to the Hypaspist Corps. Arrian refers to the two units of the corps, the Agema and the Hypaspists as the rightmost units of the first echelon of the phalanx (Arr Anab III.XI.9). The third unit, the Royal Hypaspists, is not men- 


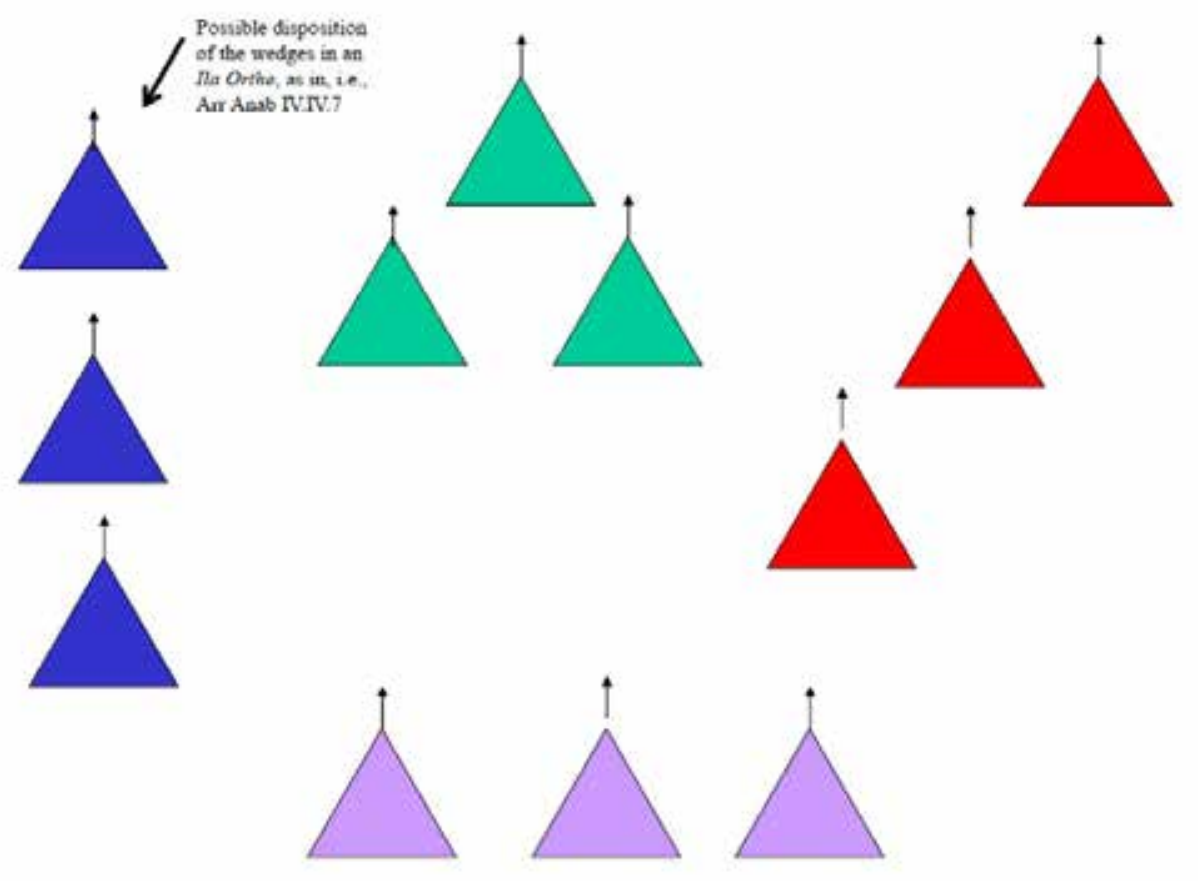

Fig.4 Possible formations of tertiary Ila, with three 50-man wedges

tioned, but only afterwards, when they were tackling scythed chariots having passed through the phalanx (Arr Anab III.XIII.6). Thus once more the most plausible model is a 2-echelon deployment, with two Chiliarchies of the corps in the front and the third at the rear, covering equal front with the two front ones by sacrificing half the normal depth.

\section{The storming of Alexander's base camp}

The issue at hand arises from the very different narratives of Arrian and Diodorus on the subject, which seem mutually exclusive, as are other parts of their respective works. Still things are not as they seem.

The latter describes a deep, planned raid to free the Persian prisoners and especially the royal family, sanctioned by Mazeus, the cavalry commander of the whole army and executed by two units (2,000 Kadusians and 1,000 Scythians) by flanking the Macedonian left (Diod XVII.LIX.5-
8). The former considers Mazeus the commander of the right Persian flank, not the cavalry commander, and assigns the raid to Persian and Indian cavalry units (Arr Anab III.XIV.4-5) infiltrating through a rupture in phalanx line. Moreover he maintains that the rear echelon about-turns, pursues these two units and defeats them after the camp has been stormed (Arr Anab III.XIV.6). As they flee, they are accidently crashing onto the Companion Cavalry which has turn left to assist the hard-pressed Macedonian left wing (Arr Anab III.XV.1) and a major engagement ensued.

This clearly does not seem plausible, to pursue in open ground cavalry with infantry and somehow being able to intercept it. Arrian probably reports two different actions, not necessarily connected: First, an infiltration and raid by Indian and Persian horse, but while the Indians are indeed counted within the elite units of the Persian center (Arr Anab III.XI.5-6) and are not mentioned or counted anywhere else, the Persians may be also elite units from the center (ibid), but they might be equally 
well regular units from the left flank (Arr Anab III. XI.3) or any cavalry unit of the empire, in a sensu lato use of the adjective "Persian". After all the elite guard cavalry of the center would have been reluctant to leave the King to execute a raid or even a charge against conventional, rank-and-file target.

Then, he narrates a bitter encounter between the Macedonian cavalry and Indian, Persian and Parthian horse (Arr Anab III.XV.1), without any more explanations. The Parthians are not counted among the cavalry which broke through and stormed the Macedonian camp (Arr Anab III. XIV.4-5). Thus it is most probable that the Companions engaged Persian, Indian and Parthian squadrons fleeing the field, without any connection or participation to the camp raid. Moreover, the Persian squadrons may well have been from the left flank (Arr Anab III.XI.3), the regular cavalry intermingled with infantry, and not the elite units from the center. The Parthians were stationed at the right flank (Arr Anab III.XI.4).

Could Diodorus account be reconciled with the above? Up to a point, it could. The detailed account of Arrian should be preferred to the much more educational, epic, biased and out-of-time, sensational narrative tale of Diodorus as a rule. Still, in this case the comparison is more balanced. Diodorus mentions the positioning of Cretan archers which do not feature at the account of Arrian. Diodorus have them positioned at the left flank (Diod XVII.LVII.4), as was their position in Arrian's account of the battle of Issus (Arr Anab II.IX.3), making it a very dependable and reliable reference. He also details fully the composition of the Greek allied cavalry in Gaugamela (Diod XVII.LVII.3) while he keeps it positioned exactly where Arrian does as well (Arr Anab III. XI.10).

On the contrary, Diodorus and Arrian disagree over the command of a phalanx Taxis. The detailed account of Arrian, over the feudal-hereditary leadership of the unit (Arr Anab III.XI.9) and the central point it had in the battle (Arr Anab III.XIV.4-5) make Arrian's reference more dependable than Diodorus plain reference (Diod XVII.LVII.2). By the same token, Diodorus account for the raid (Diod XVII.LIX.5-8) is more attractive as it gives more definite details and a perfectly plausible reasoning in intention and execution, while Arrian's account is shady and does not even clarifies the target. The fortified, main camp 60 or more stades $-12 \mathrm{~km}$ away (Arr Anab III.IX.1-2) or the provisional camp on the hillrange, less than 30 stades- $6 \mathrm{~km}$ from the scene of the main battle (Arr Anab III. IX.3-4). Thus, Arrian's account should be generally preferred, but not always-and in many cases it is wanting, plain and simple (Griffith G. T. 1947).

A very important issue, at the heart of the present discussion, is the identification and positioning of both Skythians and Kadousians which Diodorus assigns to the raid (Diod XVII.LVII.58). The Sacae, the only contingent which might be identified with the Scythians mentioned by Diodorus (another Scythian unit-possibly Dahae-was deployed with the Bactrians at the left end but was engaged against the left flankguard of Alexander) are positioned at the right flank (Arr Anab III.XI.4). This is weird, as in III.VIII.3 Arrian clearly states that they are coming along with Bessus command as allies and should thus have been deployed at the left flank-the extreme left to be more specific (Arr Anab III.XI.3). Similarly, the Cadousians are positioned at the left flank (Arr Anab III.XI.3), although Arrian clearly states that they are coming along with the Medes, who are positioned at the right flank (Arr Anab III.XI.4). It is understood that the deployment plan, recovered by the Macedonians and referred to by Arrian, in some cases was not followed, as with the elephants which were included in the written Persian plan as an extra precaution against the Companion Cavalry (Arr. Anab. III.XI.6) but were not deployed in the actual battle, as they are missing from any account of the battle.

Still, the intended positioning of these two units is problematic, especially at the level of the intended use by either Mazaeus or the Persian High Command. It cannot be determined whether this had been an ad hoc task force organized by Mazaeus, a 

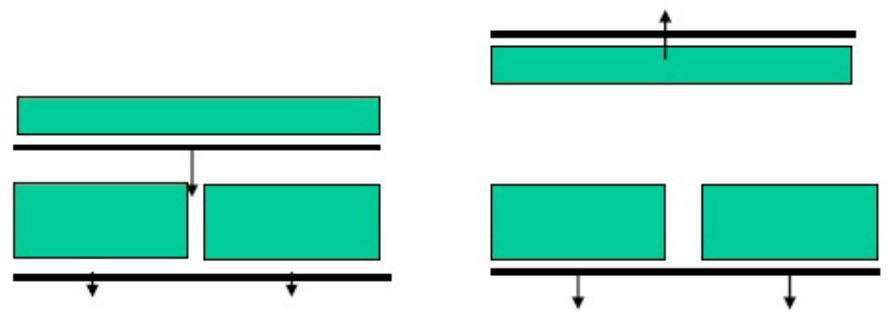

Fig. 5 The tertiary basis of phalanx organization as proposed in this manuscript suggests a double phalanx in Gaugamela which could become double-edged by executing a countermarch. The third Lochos, in half depth, double width, followed as second echelon the other two Lochoi of the Taxis, which were in normal depth side-by-side (thus forming first echelon), covering their rear in full. In this way it is ready to assist in the main effort and if the need be, meet a rear threat rapidly
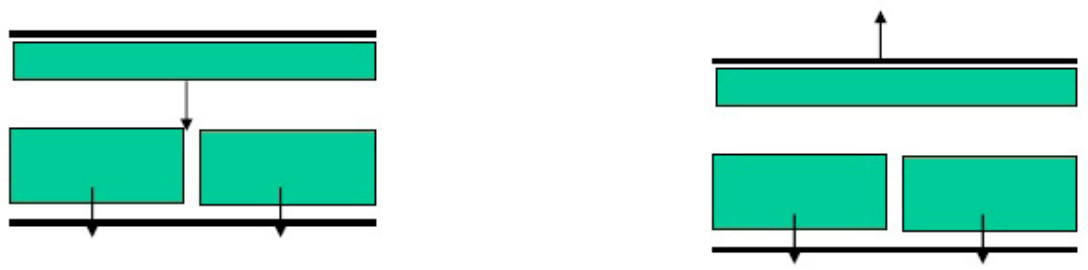

Fig. 6 The wording of Arrian for the macedonian phalanx in Gaugamela (Arr. Anab. III.XII.1) suggests a book-case double-edged phalanx, as introduced in Ars Tactica XXIX.1 by the same author. This means the second echelon is deployed with the best troops (file leaders) at the very back and file closers directly behind the file closers of the first echelon. The advantage is the prompt reaction to the rear threat; men have simply to about-face individually. The challenge is that this format offers little -if any- support to the main effort

dispatch of available units at an opportune moment of the battle, or a standing order at the army for any unit found itself in suitable position to execute this rescue mission-with a hefty reward.

It is a most reasonable assumption that the raid was launched against the main Macedonian camp, 60 or so stades away (Arr. Anab. III.IX.2). It is there that the Persian royal family and the prisoners would have been kept, along with unfit or unreliable troops (Arr. Anab. III.IX.1). Out of sight of the battle, the guard might have been less alert. If the 5,000 Thracians (Arr. Anab. III.XII.5) were assigned to this, main camp, and not to the provisional one on the ridge, the low alertness would be understood-Thracian national units were not renowned for their discipline.

\section{CONCLUSIONS}

The battle of Gaugamela was a masterpiece of planning and execution. The plan correctly anticipated reverses and provided accordingly. It was meticulous, played well the psychological card and the tactical and technical superiority of the troops of Alexander's army. Keeping large numbers of the opponent occupied by small detachments and making Darius to expend early his options and reserves is a token of high competence, not the opposite (Diod XVII.LX.1; Griffith G. T. 1947). The same must be told regarding his personal implication. Criticism for abandoning his position of a general for the one of petty officer or trooper is inaccurate and targeted to exonerate military elites who gave up the glory of participation to the security of managing and commanding. Taking on the Persian empire was an unbelievable feat needing the belief and exceptional participation of his men. The leading by example made it happen, stroke terror within the Persians and legitimized the victory, as would have done for Cyrus the Younger 70 years earlier (Xen Anab I.VIII, 26).

Arheologija i prirodne nauke (Archaeology and Science) is an Open Access Journal. All articles 
can be downloaded free of charge and used in accordance with the licence Creative Commons - Attribution-NonCommercial-NoDerivs 3.0 Serbia (https://creativecommons.org/licenses/bync-nd/3.0/rs/.

Časopis Arheologija i prirodne nauke je dostupan u režimu otvorenog pristupa. Članci objavljeni $\mathrm{u}$ časopisu mogu se besplatno preuzeti sa sajta $\mathrm{i}$ koristiti u skladu sa licencom Creative Commons - Autorstvo-Nekomercijalno-Bez prerada 3.0 Srbija (https://creativecommons.org/licenses/bync-nd/3.0/rs/.

\section{BIBLIOGRAPHY}

\section{Ancient Sources}

Aeschines, On the Embassy

Appian, Syrian Wars

Arrian, Anabasis

Arrian, Ars Tactica

Diodorus Siculus, Library

Frontinus, Stratagems

Herodotus, The Histories

Thucydides, History of the Peloponnesian War

Xenophon, Agesilaus

Xenophon, Anabasis

Xenophon, Hellenica

\section{Contemporary Scholarship}

\section{Anson, E. M. 2013}

Alexander the Great: Themes and Issues, Bloomsbury Publishing.

\section{Brunt, P. 1963}

Alexander's Macedonian Cavalry, Journal of Hellenic Studies 83: 27-46.

\section{Devine, A. M. 1975}

Grand Tactics at Gaugamela, Phoenix, Vol. 29, No. 4: 374-385.

\section{Devine, A. M. 1983}

EMBO $\Lambda$ ON: A Study in Tactical Terminology, Phoenix, Vol. 37, No. 3: 201-217.

\section{Delbruck, H. 1990}

Warfare in antiquity, Vol. 1

\section{Engels, D.W. 1980}

Alexander the Great and the Logistics of the Macedonian Army, Berkeley: University of California Press.

\section{Gaebel, R. E. 2002}

Cavalry Operations in the Ancient Greek World, University of Oklahoma Press.

\section{Green, P. 1992}

Alexander of Macedon, 356-323 B.C. A Historical Biography, Berkeley: University of California Press.

Griffith, G. T. 1947

Alexander's Generalship at Gaugamela, Journal of Hellenic Studies, Vol. 67: 77-89.

\section{Markle, M. M. 1977}

The Macedonian Sarissa, Spear, and Related Armor, American Journal of Archaeology, Vol. 81, No. 3: 323-339.

\section{Markle, M. M. 1978}

Use of the Sarissa by Philip and Alexander of Macedon, American Journal of Archaeology, Vol. 82, No. 4: 483-497.

\section{Prandi, L. 2012}

New Evidence for the Dating of Cleitarchus (POxy LXXI.4808), Histos 6: 15-26.

\section{Rzepka, J. 2008}

The Units of Alexander's Army and the District Divisions of Late Argead Macedonia, Greek, Roman and Byzantine studies 48: 39-56. 
Sekunda, N. 1989

The Persians, in: Warfare in the Ancient World, ed. John Hackett, New York.

Steele, R. B. 1922

Clitarchus, American Journal of Philology, Vol. 42, No. 1: 40-57.

\section{Stein, A. 1942}

Notes on Alexander's Crossing of the Tigris and the Battle of Arbela, The Geographical Journal, Vol. 100, No. 4: 155-164.

\section{Tarn, W. W. 1948}

Alexander the Great, Vol. 1, Cambridge: Cambridge University Press.

Wrightson, G. C. L. 2012

Greek and Near Eastern warfare 300 to 301: the development and perfection of combined arms, $\mathrm{PhD}$ Thesis, Calgary: University of Calgary.

\section{REZIME \\ BITKA KOD GAUGAMELE 331. GODINE PRE NOVE ERE: TRIJUMF TAKTIKE}

\section{KLJUČNE REČI: ALEKSANDAR VELI- KI, DARIJE III, BITKA KOD GAUGAMELE, STANDRARNI POLOŽAJ, DVOSTRUKE FAL- ANGE, TERCIJARNA ORGANIZACIJA, PRATN- JA KONJANIKA.}

Bitka kod Gaugamele 331. godine pre nove ere, bila je treća i poslednja bitka Ahemenidskog carstva, protiv nadiruće armije Aleksandra Velikog. Nasuprot detaljnim podacima, koji su manje kontradiktorni u odnosu na recimo bitku kod Granika koja se odigrala 334. godine pre nove ere, ima još uvek puno pitanja na koje nema odgovora, ali i suprotnih stavova. Koristeći antičke izvore, i upoređujući ih sa organizacijskim i tehničkim ograničenjima i mogućnostima, pokušali smo da razotkrijemo neke od činjenica o ovoj najneverovatnijoj antičkoj bici. 